\title{
Pengembangan Model Jaringan Syaraf Tiruan untuk Memprediksi Jumlah Mahasiswa Baru di PTS Surabaya (Studi Kasus Universitas Wijaya Putra)
}

\author{
Alven Safik Ritonga ${ }^{1}$, Suryo Atmojo ${ }^{2}$ \\ ${ }^{1,2}$ Program Studi Teknologi Informasi, Fakultas Teknik, Universitas Wijaya Putra \\ 1alvensafik@uwp.ac.id., ${ }^{2}$ suryoatmojo@uwp.ac.id.
}

\begin{abstract}
ABSTRAK.Jaringan Syaraf Tiruan (JST) dan data time series dapat digunakan untuk metode peramalan dengan baik. Jaringan Syaraf Tiruan adalah suatu metode yang prinsip kerjanya diadaptasi dari model matematika pada manusia atau syaraf biologi. Jaringan syaraf dikarakteristikkan oleh; (1) pola koneksi diantara neuron (disebut arsitektur), (2) menentukan bobot dari koneksi (disebut training atau learning), dan (3) fungsi aktifasi. Tujuan penelitian adalah mendapatkan arsitektur jaringan syaraf tiruan yang terbaik, membandingkan dua metode Jaringan Syaraf Tiruan Backpropogation dengan metode Jaringan Syaraf Tiruan Fungsi Basis Radial (RBF). Penelitian ini merupakan penelitian dengan menggunakan data yang sebenarnya (true experimental). Penelitian ini dilaksanakan di Universitas Wijaya Putra Surabaya, dengan memakai datasekunder yang diperoleh dari tahun 2012 sampai dengan 2016. Hasil penelitian menunjukkan adanya perbedaan antara metode JST RBF dengan metode JST Backpropagation, diperoleh indeks statistik JST RBF, MAE $=0,0074$, RMSE $=0$, 0096, error=12,6532 \%. Indeks statistik JST Backpropagation, MAE $=0,2129$, RMSE $=0,2752$, error $=13,3217 \%$.
\end{abstract}

Kata Kunci: Jaringan Syaraf Tiruan; Prediksi, Backpropagation; Fungsi Basis Radial.

ABSTRACT. Artificial Neural Network and data time series can use for good forecasting method. Artificial Neural Network is a method whose working principle is adapted from mathematical models in humans or biological neural.Neural networks are characterized by; (1)pattern of connections between the neurons(called architecture), (2)determine the weight of the connection (called training or learning), and (3)activation function.The objective of this research is to get the best artificial neural network architecture, compare two method of Backpropagation Artificial Neural Network with Radial Basis Function Artificial Neural Network (RBF).This research is a research using actual data (true experimental). This research was conducted at Wijaya Putra University Surabaya, using secondary data obtained from 2012 to 2016.The result of the research shows that there is a difference between RBF ANN method and the method of Backpropagation ANN, obtained statistical index of RBF ANN, MAE $=0.0074$, $\mathrm{RMSE}=0.0096$, error $=12.6532 \%$. Statistical index of Backpropagation ANN, MAE $=0.2129$, RMSE $=0,2752$, error $=13.3217 \%$.

Keywords: Artificial Neural Networks; Prediction; Backpropagation; Radial Basis Function.

\section{PENDAHULUAN}

Berkembangnya suatu Perguruan Tinggi salah satunya dipengaruhi oleh minat masyarakat terutama calon mahasiswa untuk menempuh pendidikan dikampus tersebut, semakin besarnya minat calon mahasiswa perlu diikuti oleh pengembangan sumber daya manusia, sarana, dan prasarana. Untuk memenuhi syarat minimum perbandingan antara jumlah mahasiswa dengan pengembangan sumberdaya manusia, sarana, dan prasarana perlu dilakukan prediksi berapa besar peningkatan jumlah mahasiswa tiap tahunnya. Metode Jaringan Syaraf Tiruan (JST) dan data time series secara efektif digunakan untuk mendapatkan model prediksi peningkatan jumlah mahasiswa baru.

Jaringan Syaraf Tiruan (JST) adalah pemproses sistem informasi dengan karakteristik tertentu dan performa yang mendekati syaraf biologi (Fauset, 1994). Jaringan syaraf adalah merupakan salah satu representasi buatan otak manusia. Hal ini dikarenakan pemrosesan informasi terletak pada suatu neuron yang memiliki sinyal. Pada tiap neuron masukan dan neuron keluaran memiliki lapis tersembunyi (hidden layer). Penerapan jaringan syaraf tiruan telah banyak digunakan peneliti sebelumnya, Ye (2012) menerapkan jaringan syaraf tiruan untuk memprediksi fluktuasi nilai tukar RMB Exchange di People's Bank China, Kurt dan Oktay (2010) menggunakan jaringan syaraf tiruan untuk memprediksi tingkat polusi udara, Wang et al.(2012) meramalkan beban listrik jangka pendek pada perencanaan distribusi listrik, Huang dan Foo (2002) membuat model prediksi kadar salinitas air sungai menggunakan metode jaringan syaraf tiruan, dan Irawan et al. (2013), menggunakan jaringan syaraf tiruan untuk memprediksi curah hujan dan klimatologi. Berdasarkan penelitian-penelitian diatas, maka menurut peneliti metode jaringan syaraf tiruan ini perlu diterapkan untuk memprediksi peningkatan jumlah mahasiswa baru, karena dengan menggunakan metode ini memperoleh keakuratan yang bagus dan proses yang cepat. 
Penelitian ini akan mengembangkan Metode Jaringan Syaraf Tiruan Backpropagation (BP) dan Jaringan Syaraf Tiruan Fungsi Basis Radial (RBF) yang diimplementasikan dengan menggunakan program komputer yang mampu menyelesaikan sejumlah proses perhitungan selama proses pembelajaran (Kusumadewi, 2004).

\subsection{Metode Jaringan Syaraf Tiruan Fungsi Basis Radial (RBF)}

Gupta (2003) menyatakan bahwa Jaringan Syaraf Fungsi Basis Radial yang merupakan alternatif dari Multilayered feedforward Neural network (MFNNs) telah dikembangkan. Jaringan syaraf Fungsi Basis Radial adalah model jaringan syaraf dengan satu unit pada hidden layer, dimana fungsi aktivasinya adalah fungsi basis dan fungsi linear pada lapisan output. Model ini merupakan pemetaan fungsi nonlinier multidimensi berdasar pada jarak antara vektor input dan vektor pusat.Jaringan Syaraf Fungsi Basis Radial

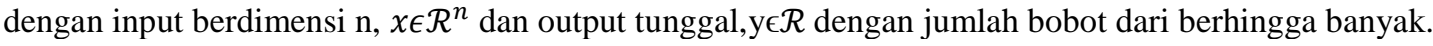

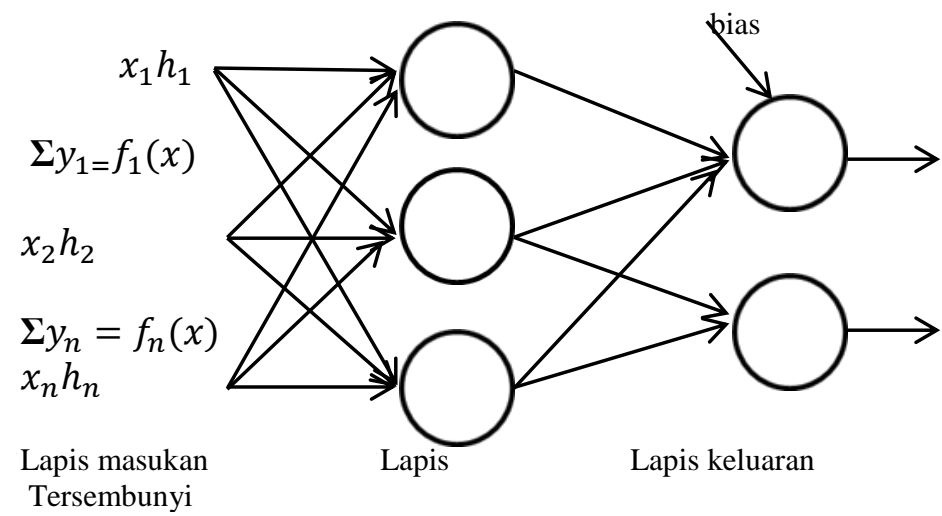

Gambar 1. Arsitektur Jaringan Fungsi Radial Basis

Secara matematis output y dapat dinyatakan,

$y=f(x)=\sum_{i=1}^{n} w_{i} \phi_{i}\left(\left\|x-c_{i}\right\|\right)$

$h(x)=\phi\left(\left\|x-c_{i}\right\|\right)=\phi\left((x-c)^{T} R^{-1}(x-c)\right)$

fungsi $\phi\left(\left\|x-c_{i}\right\|\right)$ dan $\mathrm{h}(\mathrm{x})$ adalah Fungsi Basis Radial dari $\mathrm{x}$ dan $w_{i}$ adalah parameter bobot, diperoleh dengan menggeser $\phi_{i}(\|x\|)$ sejauh pusat $c_{i}$.

\subsection{Metode Jaringan Syaraf Tiruan Backpropagation (BP)}

Arsitektur Backpropagation merupakan model untuk peramalan time series dengan menggunakan jaringan syaraf tiruan Feedforward, input layer terhubung ke output layer melalui satu atau lebih hidden layer. Arsitektur backpropagation menggunakan error output untuk mengubah nilai bobot-bobotnya dalam arah mundur (backward) Kusumadewi(2004). Pada saat perambatan maju, neuron-neuron diaktifkan dengan menggunakan fungsi aktivasi yang didefenisikan, seperti sigmoid:

$y=f(x)=\frac{1}{1+e^{-\sigma x}}$

atau tansig:

$y=f(x)=\frac{e^{x}-e^{-x}}{e^{x}+e^{-x}}$

Gambar 2 di bawah ini adalah arsitektur backpropagation dengan $\mathrm{n}$ buah input (ditambah sebuah bias), sebuah layer tersembunyi (hidden layer) yang terdiri dari $\mathrm{p}$ unit (ditambah sebuah bias), serta $\mathrm{m}$ buah unit output.

$v_{j i}$ bobot yang menghubungkan neuron input $X_{i}$ ke neuron pada hidden layer $Z_{j} \cdot v_{j 0}$ adalah bobot yang menghubungkan bias di neuron input ke neuron hidden layer $Z_{j} \cdot w_{k j}$ adalah bobot dari neuron hidden layer $Z_{j}$ ke neuron keluaran $y_{k}, w_{k 0}$ adalah bobot dari bias di hidden layer ke neuron keluaran $y_{k}$. Fungsi aktivasi yang digunakan, antara lapisan input dan hidden layer, dan antara hidden layer dengan lapisan output adalah fungsi aktivasi logsig. 


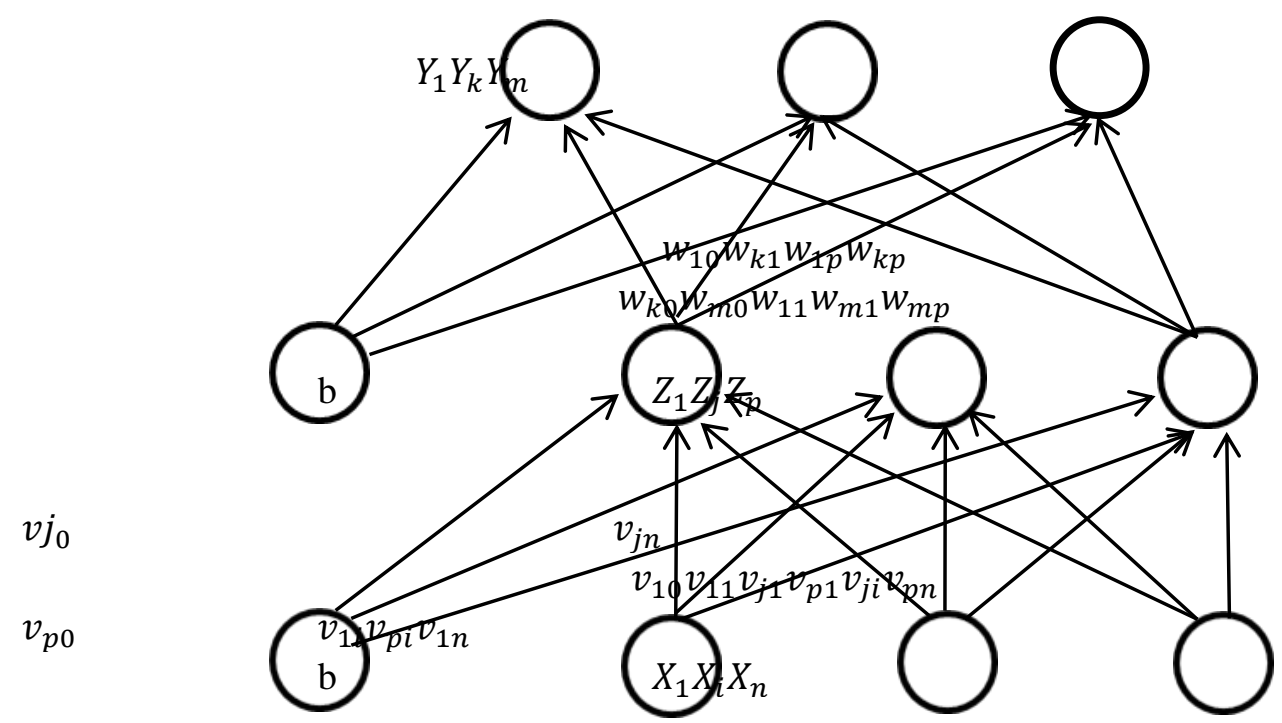

Gambar 2 Arsitektur Jaringan Backpropagation

\section{METODE PENELITIAN}

\subsection{Studi Literatur}

Melakukan kajian artikel ilmiah untuk mengetahui perkembangan dan metoda-metoda yang baru penelitian di bidang penerapan Jaringan Syaraf Tiruan. Literatur yang digunakan adalah artikel-artikel ilmiah pada jurnal internasional dan jurnal nasional yang membahas mengenai penerapan Jaringan Syaraf Tiruan untuk memprediksi di semua bidang, misalnya: bidang industri, bidang klimatologi, bidang lingkungan hidup, bidang energi, dan bidang ekonomi.

\subsection{Pengumpulan Data}

Dalam menyelesaikan penelitian ini, dilakukan pengambilan data dan kemudian dilanjutkan dengan validasi data. Data yang digunakan pada penelitian ini adalah data sekunder yang diambil dari Biro Kemahasiswaan Universitas Wijaya Putra Surabaya, beralamat Jalan Raya Benowo No. 1-3 Surabaya. Data yang digunakan adalah data jumlah calon mahasiswa baru yang mendaftar setiap tahun selama 5 tahun terakhir yaitu tahun 2012-2016. Data jumlah calon mahasiswa baru yang diambil berdasarkan asal daerah kabupaten/kota masing-masing mahasiswa baru, antara lain: Surabaya, Gresik, Lamongan, Mojokerto, Pasuruan, dan kabupaten/kota lainnya. Validasi data dilakukan supaya data-data yang sudah diambil dapat menjadi data input dan data target yang sesuai untuk training dan testing pada Jaringan Syaraf Tiruan.

\subsection{Pengolahan Data}

Setelah data divalidasi, data jumlah mahasiswa baru berdasarkan asal daerah calon mahasiswa masing-masing sudah bisa digunakan sebagai data input. Pengelompokan data dapat digambarkan seperti Tabel 1 berikut ini.

Tabel 1. Data Input Untuk Prediksi

\begin{tabular}{ccrcccc}
\hline \multirow{2}{*}{ Tahun } & \multicolumn{6}{c}{ Kabupaten Kota } \\
\cline { 2 - 7 } & Surabaya & Gresik & Lamongan & Mojokerto & Pasuruan & $\begin{array}{c}\text { Kabupaten/ } \\
\text { Kota Lain }\end{array}$ \\
\hline $2012 / 2013$ & $\mathrm{X}_{1}$ & $\mathrm{X}_{2}$ & $\mathrm{X}_{3}$ & $\mathrm{X}_{4}$ & $\mathrm{X}_{5}$ & $\mathrm{X}_{6}$ \\
$2013 / 2014$ & $\mathrm{X}_{7}$ & $\mathrm{X}_{8}$ & $\mathrm{X}_{9}$ & $\mathrm{X}_{10}$ & $\mathrm{X}_{11}$ & $\mathrm{X}_{12}$ \\
$2014 / 2015$ & $\mathrm{X}_{13}$ & $\mathrm{X}_{14}$ & $\mathrm{X}_{15}$ & $\mathrm{X}_{16}$ & $\mathrm{X}_{17}$ & $\mathrm{X}_{18}$ \\
$2015 / 2016$ & $\mathrm{X}_{19}$ & $\mathrm{X}_{20}$ & $\mathrm{X}_{21}$ & $\mathrm{X}_{22}$ & $\mathrm{X}_{23}$ & $\mathrm{X}_{24}$ \\
$2016 / 2017$ & $\mathrm{X}_{25}$ & $\mathrm{X}_{26}$ & $\mathrm{X}_{27}$ & $\mathrm{X}_{28}$ & $\mathrm{X}_{29}$ & $\mathrm{X}_{30}$ \\
\hline
\end{tabular}


Selanjutnya data yang sudah dikelompokkan berdasarkan asal kabupaten/kota calon mahasiswa baru tiap tahun untuk memprediksi untuk tahun berikutnya. Pada penelitian ini data input dibagi menjadi dua bagian yaitu data untuk training (pelatihan) dan data testing (pengujian).

\subsection{Preprocessing Data}

Sebelum data input dimasukkan kedalam jaringan terlebih dahulu data di transformasi kedalam bentuk data interval. Data-data tersebut dinormalisasi sehingga menjadi data yang berada dalam selang [0,1], normalisasi menggunakan rumus Min-max normalisasi (Han, Kamber, dan Pei, 2012). Misalkan data input $\mathrm{X}$ dengan jumlah data $\mathrm{n}, \mathrm{x}_{1}, \mathrm{x}_{2}, \ldots, \mathrm{x}_{\mathrm{n}}$.

$$
\mathrm{Z}=\frac{\mathrm{X}-\mathrm{X}_{\min }}{\mathrm{X}_{\max }-\mathrm{X}_{\min }} \cdot\left(\mathrm{B}_{\max }-\mathrm{B}_{\operatorname{mim}}\right)+\mathrm{B}_{\min }
$$

dengan:

$$
\begin{aligned}
& \mathrm{X} \\
& \mathrm{X}_{\text {min }}=\text { data input } \\
& \mathrm{X}_{\max }=\text { data } \mathrm{X} \text { minimum } \\
& \mathrm{B}_{\max }=\text { batas atas interval } \\
& \mathrm{B}_{\min }=\text { batas bawah interval }
\end{aligned}
$$

Tujuan dari normalisasi adalah menyamakan selang dari nilai-nilai tiap data sehingga setiap data memiliki peran yang proporsional dalam setiap proses.

\subsection{Perancangan Arsitektur Jaringan Syaraf Tiruan (JST)}

Langkah selanjutnya adalah perancangan arsitektur jaringan yang terbaik menerjemahkan atau menganalisa parameter-parameter dalam suatu jaringan, antara lain:

1) Untuk mendapatkan model Backpropagation yang sesuai, perlu menentukan kombinasi yang tepat antara jumlah neuron (unit) pada lapisan input, jumlah neuron pada lapisan tersembunyi (hidden layer). Backpropagation merupakan algoritma pembelajaran terawasi (supervised) dengan mempunyai banyak lapisan untuk mengubah bobot-bobot yang terhubung dengan neuron-neuron yang ada pada lapisan tersembunyinya, jadi perlu ditentukan inisialisasi bobot (bobot awal).

2) Untuk mendapatkan model Fungsi Basis Radial yang sesuai, perlu menentukan kombinasi yang tepat antara jumlah input, jumlah node (cluster) pada unit lapisan tersembunyi (hidden layer), nilai pusat (center), dan standar deviasi (lebar) dari input pada setiap node.

3) Berdasarkan rancangan JST Backpropagation dan Fungsi Basis Radial kemudian peneliti akan merancang dan menterjemahkan algoritma training dan diimplementasikan menggunakan Matlab untuk menentukan prediksi peningkatan jumlah calon mahasiswa baru.

4) Menggunakan hasil implementasi di atas, kemudian peneliti menganalisa dan membahas hasil prediksi oleh Jaringan Syaraf Tiruan Backpropagatian dan Fungsi Basis Radial. Pengujian kehandalan rancangan arsitektur jaringan yang dibuat digunakan beberapa indeks statistik yaitu; Mean Absolut Error (MAE) dan Root Mean Square Error (RMSE). Dari pengujian kehandalan jaringan kemudian dibandingkan kedua metode yang digunakan yaitu Backpropagation dan Fungsi Basis Radial. 


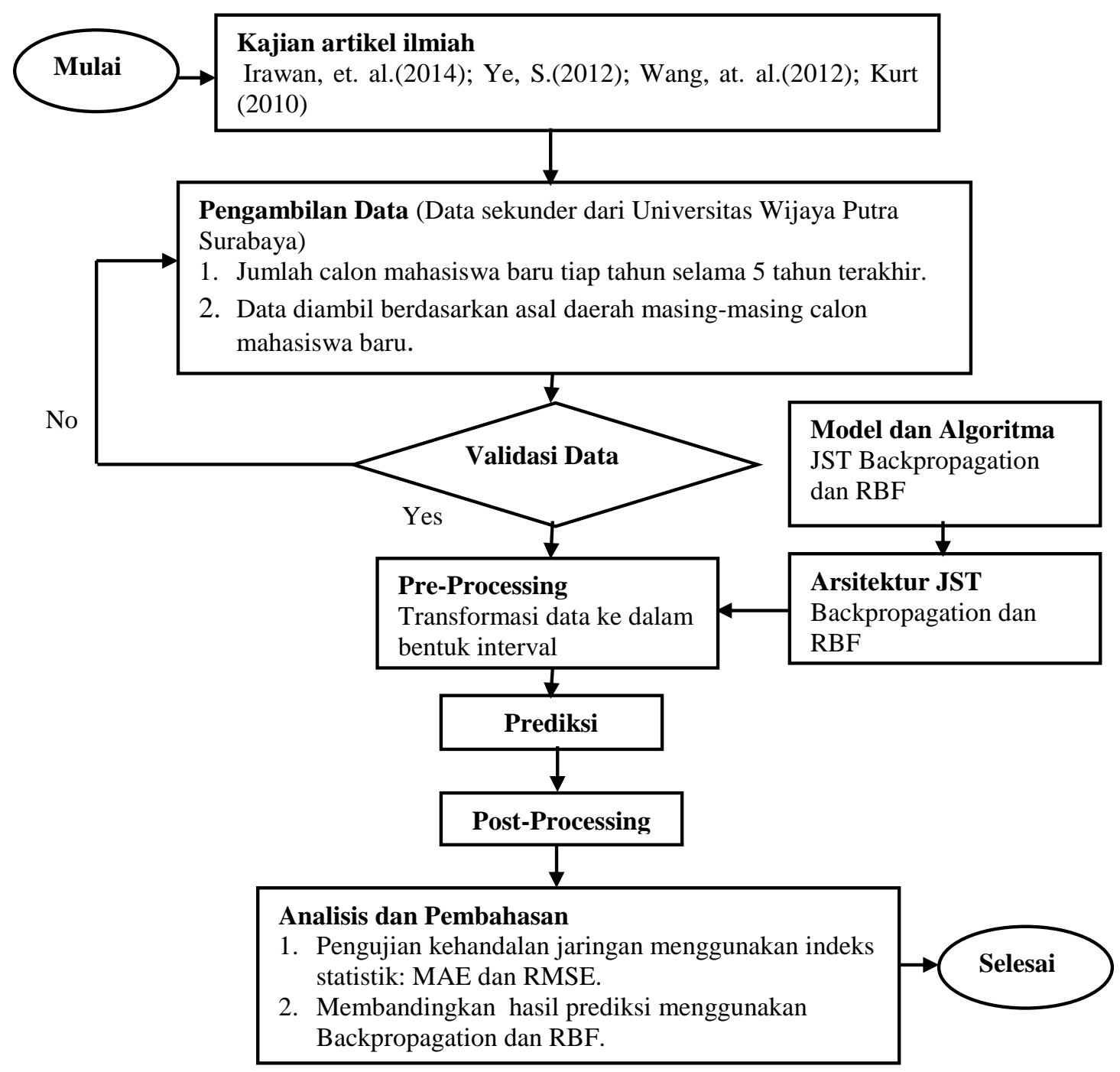

Gambar 3. Diagram Tahap Penelitian

\section{HASIL DAN PEMBAHASAN}

\subsection{Pengambilan Data}

Data yang digunakan adalah data jumlah calon mahasiswa baru Universitas Wijaya Putra Surabaya yang mendaftar setiap tahun selama 5 tahun terakhir yaitu tahun 2012-2016 diambil berdasarkan asal daerah kabupaten/kota masing-masing mahasiswa baru, seperti pada Tabel 2 berikut ini. 
Tabel 2. Data Jumlah Mahasiswa Baru Universitas Wijaya Putra

\begin{tabular}{lcccccc}
\hline \multirow{2}{*}{ Tahun } & \multicolumn{7}{c}{ Kabupaten/Kota } \\
\cline { 2 - 6 } & Surabaya & Gresik & Lamongan & Mojokerto & Pasuruan & $\begin{array}{c}\text { Kabupaten/ } \\
\text { Kota Lain }\end{array}$ \\
\hline $2012 / 2013$ & 319 & 152 & 93 & 122 & 161 & 584 \\
$2013 / 2014$ & 338 & 154 & 92 & 69 & 159 & 683 \\
$2014 / 2015$ & 338 & 167 & 72 & 81 & 114 & 618 \\
$2015 / 2016$ & 578 & 252 & 60 & 49 & 134 & 223 \\
$2016 / 2017$ & 451 & 182 & 21 & 61 & 127 & 191 \\
\hline
\end{tabular}

3.2 Pengolahan Data

Sebelum data input dimasukkan ke dalam jaringan terlebih dahulu data di transformasi kedalam bentuk data interval. Data-data tersebut dinormalisasi sehingga menjadi data yang berada dalam selang [0,1], normalisasi menggunakan rumus Min-max normalisasi (Han, Kamber, dan Pei, 2012). Pada penelitian ini data input dibagi menjadi dua bagian yaitu data untuk training (pelatihan) dan data testing (pengujian), yang diperlihatkan pada Tabel 3 dan Tabel 4, berikut ini.

Tabel 3. Data Pelatihan Untuk Prediksi Jumlah Mahasiswa Baru Universitas Wijaya Putra

\begin{tabular}{ccccccc}
\hline No & $\mathrm{X}_{1}$ & $\mathrm{X}_{2}$ & $\mathrm{X}_{3}$ & $\mathrm{X}_{4}$ & $\mathrm{X}_{5}$ & $\mathrm{X}_{6}$ \\
\hline 1 & 0,1979 & 0,1088 & 0,1526 & 0,2115 & 0,8505 & 0,1979 \\
2 & 0,2009 & 0,1073 & 0,0725 & 0,2085 & 1,0000 & 0,2009 \\
3 & 0,2205 & 0,0770 & 0,0906 & 0,1405 & 0,9018 & 0,2205 \\
4 & 0,3489 & 0,0589 & 0,0423 & 0,1707 & 0,3051 & 0,3489 \\
\hline
\end{tabular}

Tabel 4. Data Pengujian Untuk Prediksi Jumlah Mahasiswa Baru Universitas Wijaya Putra

\begin{tabular}{ccccccc}
\hline No & $\mathrm{X}_{1}$ & $\mathrm{X}_{2}$ & $\mathrm{X}_{3}$ & $\mathrm{X}_{4}$ & $\mathrm{X}_{5}$ & $\mathrm{X}_{6}$ \\
\hline 5 & 0,2432 & 0,0000 & 0,0604 & 0,1601 & 0,2568 & 0,2432 \\
\hline
\end{tabular}

\subsection{Implementasi Arsitektur JST Fungsi Radial Basis}

Langkah pertama yang dilakukan adalah menentukan parameter arsitektur yang peneliti gunakan pada penelitian ini sebagai berikut.
$>$ Jumlah Node
$: 30$
$>$ Target Error $\quad: 0,0001$
$>>$ Learning Rate $\quad: 0,01$
$>>$ Fungsi Aktivasi : Fungsi Gaussian

Arsitektur jaringan disimulasikan dengan menggunakan Matlab. Iterasi proses traning dihentikan pada epoch ke-20, karena sudah mencapai maksimum epoch meskipun performance tujuan $(0,0001)$ belum tercapai (Fungsi Performance $=0,00023$ ), proses tersebut diperlihatkan pada Gambar 2 berikut ini.

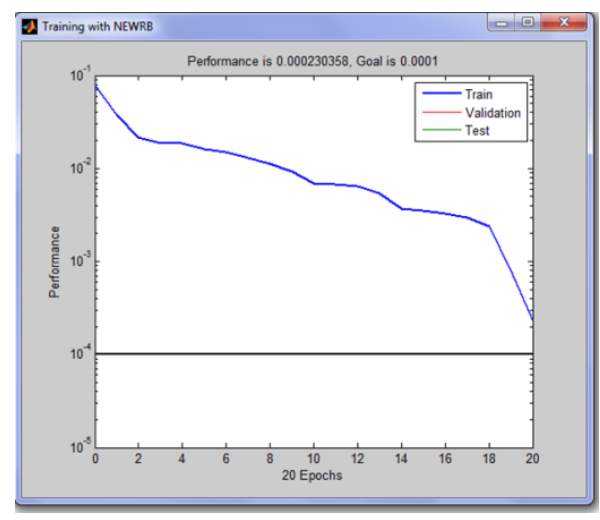

Gambar 2. Proses Training JST Fungsi Radial Basis Tercapai 
Hasil simulasi dengan menggunakan parameter-parameter di atas, diperoleh hasil prediksi dan error untuk tahun 2016, dapat dilihat pada Tabel 5 dibawah ini.

Tabel 5. Hasil Prediksi dan Error Jumlah Mahasiswa Baru Tahun 2016

\begin{tabular}{lccc}
\hline Kabupaten/Kota & Aktual & Prediksi & Error \\
\hline Surabaya & 451 & 578 & 127 \\
Gresik & 182 & 252 & 70 \\
Lamongan & 21 & 60 & 39 \\
Mojokerto & 61 & 49 & 12 \\
Pasuruan & 127 & 134 & 7 \\
Kabupaten/Kota Lain & 191 & 223 & 32 \\
\hline
\end{tabular}

Hasil prediksi diatas ditunjukkan pada grafik di Gambar 3 berikut ini.

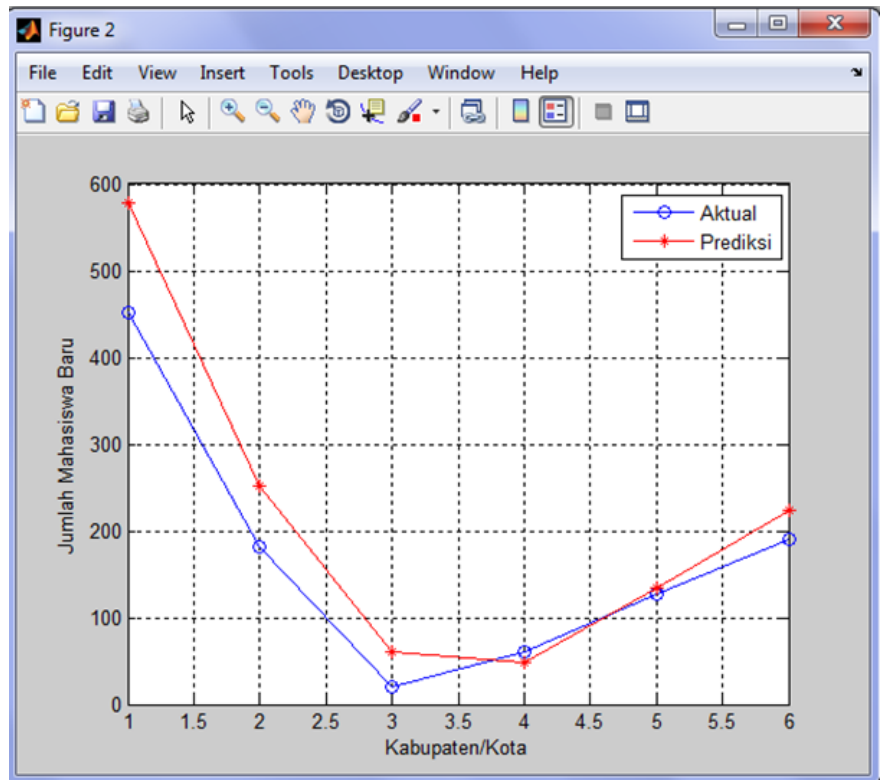

Gambar 3. Grafik Prediksi Jumlah Mahasiswa Baru tahun 2016

Menggunakan jaringan tersebut di atas, bisa dicari prediksi jumlah mahasiswa baru tahun 2017, dengan hasil ditunjukkan pada Tabel 6 berikut ini.

Tabel 6. Prediksi Jumlah Mahasiswa Baru Tahun 2017

\begin{tabular}{llccccc}
\hline Kabupaten/Kota & Surabaya & Gresik & Lamongan & Mojokerto & Pasuruan & $\begin{array}{c}\text { Kabupaten/ } \\
\text { Kota Lain }\end{array}$ \\
\hline Prediksi & 450 & 188 & 27 & 52 & 128 & 188 \\
\hline
\end{tabular}

\subsection{Implementasi Arsitektur JST Backpropagatin}

Dengan mengunakan contoh data traning yaitu jumlah mahasiswa baru tahun 2012 sampai dengan 2015, dan sebagai contoh data testing yaitu data jumlah mahasiswa baru tahun 2016. Dan parameterparameter yang digunakan, sebagai berikut ini;

$>>$ net.trainParam.epochs $=10000$;

$>>$ net.trainParam.goal $=0.0001$;

$>$ net.trainParam.max_perf_inc $=1.04$;

$>>$ net.trainParam.lr=0.01;

$>$ net.trainParam.lr_inc $=1.05$;

$>>$ net.trainParam.lr_dec $=0.7$;

$>$ net.trainParam. $m c=0.9$;

$>$ net.trainParam. show $=200$; 
Menggunakan fungsi aktivasi "tansig" untuk semua layer, dan menggunakan "traingd" untukfungsi training. Iterasi dihentikan pada epoch ke-10000, karena sudah mencapai maksimum epoch meskipun performance tujuannya $(0,0001)$ belum tercapai (Fungsi Performance=0,00428), ditunjukkan pada Gambar 4 berikut ini.

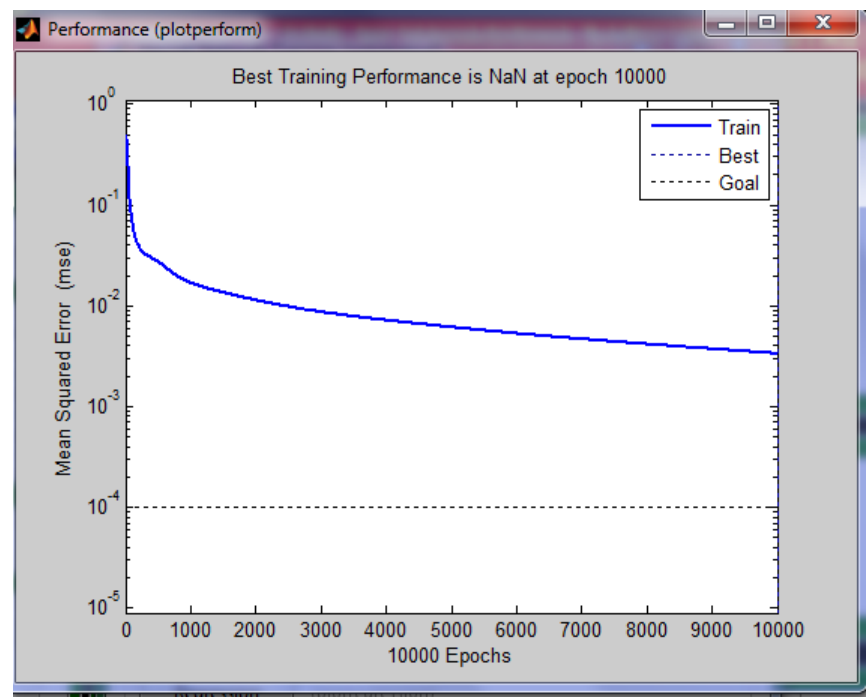

Gambar 4. Proses Training Pada Traingd JST Backpropagation

Hasil simulasi dengan menggunakan parameter-parameter diatas, diperoleh hasil prediksi dan error untuk tahun 2016, dapat dilihat pada Tabel 7 berikut ini.

Tabel 7. Hasil Prediksi dan Error Jumlah Mahasiswa Baru Tahun 2016

\begin{tabular}{lccc}
\hline Kabupaten/Kota & Aktual & Prediksi & Error \\
\hline Surabaya & 451 & 662 & 212 \\
Gresik & 182 & 251 & 69 \\
Lamongan & 21 & 169 & 148 \\
Mojokerto & 61 & 80 & 19 \\
Pasuruan & 127 & 55 & 72 \\
Kabupaten/Kota Lain & 191 & 135 & 56 \\
\hline
\end{tabular}

Hasil prediksi diatas bisa dilihat pada grafik di Gambar 5 berikut ini.

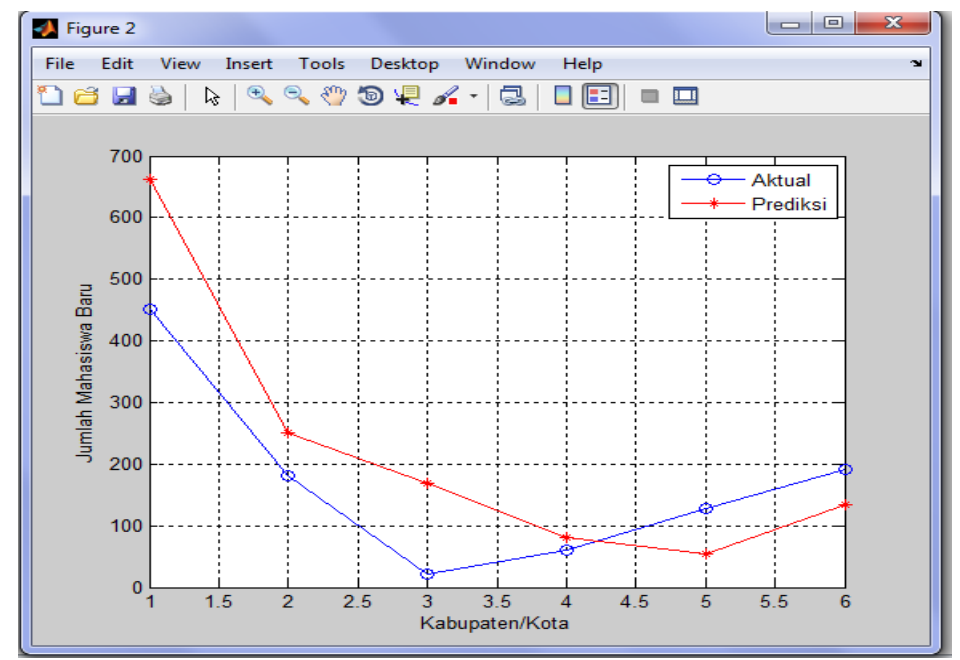

Gambar 5. Grafik Prediksi Jumlah Mahasiswa Baru tahun 2016

Dengan menggunakan jaringan tersebut, bisa dicari prediksi jumlah mahasiswa baru tahun 2017, dengan hasil pada Tabel 8, sebagai berikut. 
Tabel 8. Prediksi Jumlah Mahasiswa Baru Tahun 2017

\begin{tabular}{lcccccc}
\hline Kabupaten/Kota & Surabaya & Gresik & Lamongan & Mojokerto & Pasuruan & $\begin{array}{c}\text { Kabupaten/ } \\
\text { Kota Lain }\end{array}$ \\
\hline Prediksi & 575 & 6 & 48 & 385 & 436 & 206 \\
\hline
\end{tabular}

\subsection{Perbandingan JST Fungsi Radial Basis dan JST Backpropagation}

Observasi dan model prediksi yang menggunakan kedua metode ini pada data jumlah mahasiswa baru periode 2012-2016 digambarkan pada Gambar 3 dan Gambar 5. Dengan menggunakan parameter yang sama yaitu, target error $=0,0001$ dan learning rate $=0,01$, kedua metode ini memberikan hasil performance yang berbeda, seperti yang ditampilkan pada Tabel 9 berikut ini.

Tabel 9. Statistik Performance JST RBF dan Backpropagation

\begin{tabular}{lcc}
\hline Performance & JST RBF & JST Backpropagation \\
\hline MAE & 0,0074 & 0,2129 \\
RMSE & 0,0096 & 0,2752 \\
Error & $12,6532 \%$ & $13,3217 \%$ \\
\hline
\end{tabular}

\section{KESIMPULAN DAN SARAN \\ 4.1 Kesimpulan}

Hasil simulasi dan analisis data yang dilakukan, maka dapat diperoleh suatu kesimpulan berikut ini;

1. Model prediksi yang terbaik menggunakan metode JST RBF dengan parameter-parameter, Target Error $=0,0001$ dan Learning Rate $=0,01$. Menggunakan metode JST Backprobagation dengan parameter-parameter, Target Error $=0,0001$ dan Learning Rate $=0,01$, dengan fungsi aktivasi "tansig"untuk semua layer, dan fungsi "traingd" untuk fungsi training.

2. Menggunakan parameter-parameter (Target Error=0,0001 dan Learning Rate=0,01) yang sama pada kedua metode dalam memprediksi jumlah mahasiswa baru di Universitas Wijaya Putra Surabaya, diperoleh perbedaan pada indeks statistik MAE, RMSE, dan Error. Indeks statistik menggunakan metode JST RBF diperoleh MAE=0,0074, RMSE=0,0096, dan error=12,6532\%. Indeks statistik menggunakan metode JST Backpropagation diperoleh MAE $=0,2129$, RMSE $=0,2752$, dan error $=13,3217 \%$. Dari perbandingan indeks statistik ini bisa disimpulkan bahwa metode JST RBF lebih baik dalam memprediksi jumlah mahasiswa baru.

3. Dengan menggunakan data jumlah mahasiswa baru Universitas Wijaya Putra periode tahun 2012-2016 sebagai data training dan data testing, diperoleh prediksi jumlah mahasiswa baru menggunakan metode JST RBF diperoleh, Surabaya=450, Gresik=188, Lamongan=27, Mojokerto=52, Pasuruan=128, dan Kabupaten/Kota Lain=188. Menggunakan metode JST Backpropagation hasil prediksi; Surabaya=575, Gresik=6, Lamongan=48, Mojokerto=385, Pasuruan=436, dan Kabupaten/Kota Lain=206.

\subsection{Saran}

Diharapkan dalam prediksi jumlah mahasiswa baru, bukan hanya dilakukan untuk Universitas Wijaya Putra Surabaya saja, tapi bisa untuk kampus-kampus lain juga bisa diterapkan.

\section{DAFTAR PUSTAKA}

Fauset, L. (1994).Fundamental of Neural Network, Prentice Hall, New York.

Gupta, M. M., Jin, L., and Homma, N. (2003).Static ang Dynamic Neural Network, from Fundamental to Advanced Theory, Wiley-Interscience, New Jersey.

Han, J., Kamber,M., dan Pei, J. (2012), Data Mining Concepts and Techniques, Morgan Kaufmann Publishers, Waltham.

Huang, W., Foo, S. (2002). Neural network modeling of salinity variation in Apalachicola River. Water Research, 36, 356-362.

Irawan, M.I., Syaharuddin, Utomo, D.B., dan Mustikarukmi, A. (2013). Intelligent Irrigation Water Requirement System Based on Artificial Neural Networks and Profit Optimization for Planting Time 
Decision Making of Crops in Lombok Islands. Journal of Theoretical and Applied Information Technology, 58(3), 657-671.

Kurt, A., Oktay. A. B. (2010). Forecasting air pollutant indicator levels with geographic models 3 days in advance using neural networks. Expert Systems with Applications, 37, 7986-7992. doi:10.1016/j.eswa.2010.05.093.

Kusumadewi, S.(2004). Membangun Jaringan Syaraf Tiruan Menggunakan Matlab dan Excel Link, Graha Ilmu, Yogyakarta.

Ye, S. (2012). RMB Exchange Rate Forecast Approach Based on BP Neural Network. Physics Procedia, 33, $287-293$. doi:10.1016/j.phpro.2012.05.064.

Wang, Y., Niu, D., Ji, L. (2012). Short-term power load forecasting based on IVL-BP neural network technology. Systems Engineering Procedia, 4, 168 - 174. doi:10.1016/j.sepro.2011.11.062. 